\title{
The Principal Leadership in Developing Inclusive Education for Diverse Students
}

\author{
Shinta Setia1 ${ }^{1}$ Pwee Leng' ${ }^{2}$ Yurilla Endah Muliatie ${ }^{3}$ Dian Ekowati ${ }^{4}$ Dwi Ratmawati $^{5}$ \\ 1, 2, 3, 4, 5 Airlangga University, Indonesia
}

\begin{abstract}
Zonasi, a new 'zoning-based school' system implemented by the Indonesian government in June 2019 has created a significant impact on student enrollment in all public schools across the country. Before June 2019, student enrollment in public schools were based on its school's selection process, mainly academic achievement, whilst for past 2 years (2019 and 2020) students' enrollment has been based on "zonasi", a geographical distance between student's home and the chosen school. The closer the distance, the bigger chance to get acceptance. As result, public schools nowadays have more diverse students than before. This research aimed to explore leadership practices of secondary public-school principal in transforming a regular public school into inclusive public school through the act of leadership practices. The school was acknowledged by local government and communities as one of the successful inclusive public high school in Surabaya. This research used a qualitative approach within a case study design. The data collection techniques used in this research were interviews, observations, and school documents. Data were collected from the principal, 2 counseling teacher, 2 special education teachers, and head of educational in the district. The result revealed four principal leadership behavior to transform regular public school into inclusive public school i.e. (1) changing mindset, the teachers and non-academic staffs, (2) promoting inclusive practices within the school through various programs, (3) promoting inclusive practice in teaching-learning process, (4) building connection with parents \& local communities, and seeking government support on the initiatives. This study only investigated one public school, with the involvement of a school principal and 4 teachers. It would be better if the scope of the research could be broader, for example covering elementary and high schools, and involving more participants, such as the vice principal of the curriculum field, students and parents. This study contributes to leadership research in the context of secondary school education, which has undergone a transformation from the previously students tend to be homogeneous because they are based on standardized academic qualification, nowadays students at schools have more diverse social backgrounds as a result of the implementation of the zoning system in Indonesia. The findings of this paper can be used as a tool. a guide for policy makers and educational planners regarding zoning system in Indonesia. Such practices can also be learned, adapted and imitated by other schools.
\end{abstract}

Keywords: Leadership behavior, Inclusive education, Diversity

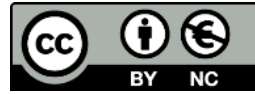

This is an open access article under the CC-BY-NC license

\section{INTRODUCTION}

Although inclusive education has been agreed and implemented in many countries almost three decades ago, the implementation of inclusive education for children with special need in Indonesia has just begun two decades later. According to Poernomo (2016) as a commitment of the Indonesian government, the implementation of inclusive education for the disable started in 2002 when the government officially started pilot projects in nine provinces which have resource centers. Since then, there are more than 1500 students with disabilities were enrolled in mainstream schools. In 2005 the number increased to 6,000 students or $5.11 \%$ of the total number of children with special needs. Whereas in 2007 increased to $7.5 \%$ or 15181 students in 796 
inclusive schools which consists of 17 kindergartens, 648 primary schools, 75 secondary schools and 56 senior high schools.

Moreover, to encourage the implementation of inclusive education more broadly, a national workshop was held in Bandung that produced Bandung Declaration in which the content was among others encourage the government, educational institutions, relevant institutions, business and industry and the community to ensure any children to get equal access to all aspects of life, as well as getting humane treatment (Poernomo, 2016).

When tracking back the history, the notion of education for individuals with special needs actually has been embedded far before Indonesia received its Independence Day in 1945. As stated by Sunardi, Gunarhadi \& Yeager (2011) in 1901, Pioneer Ch. A. Westhoff opened a sheltered workshop for the blind in Bandung. Also, in Bandung in 1927, a school for the mentally retarded was opened by Vereniging Bijzonder Onderwijs, promoted by Folker, so that the school became known as the Folker School. The first school for the deaf-mute was initiated in Bandung in 1930 by C. M.Roelfsema. After Indonesia's independence, a few special schools were established in other regions, mostly managed by private foundations, consisting of special school types for the blind, the deaf-mute, the mentally retarded, the physically handicapped, and the emotionally disturbed.

Furthermore, the National motto of 'Bhinneka Tunggal Ika' (unity in diversity) represents a national confession to stay united in spite of significant social, multiethnic diverse state and geographical challenges (Sheehy \& Budiyanto, 2015).

In terms of legal matters, constitution of the Republic of Indonesia 1945 stated clearly and unequivocally guarantee that every Indonesian citizen has the right to education, which was emphasized by the Direction Letter of the Directorate General of Primary and Secondary Education No. 38/C.66/MN/2003, dated 20 January 2003 on National Education System about Special Education in Regular Schools. This Direction Letter stated that every district must operate at least four inclusive schools, one primary, secondary, general high and vocational higher type.

By 2008, there were 925 inclusive schools existed in Indonesia. The inclusive policy then received strong legal support by the Decree of the Minister of Education No 70-2009 concerning inclusive Education for Students with Disabilities and with Special Talents. It stated that every district must operate at least one inclusive high school and every sub district must operate at least one primary and one secondary inclusive school. This inclusive education is for students with potential intelligence and/or other special talent (Sunardi, Gunarhadi \& Yeager, 2011)

In Surabaya, the second biggest city in Indonesia, where we conducted the research, the inclusive education in public school itself has been initiated since 2014 by two regular high school among 63 public secondary schools in the city.

Although the number of inclusive schools has continued to growth, it is a gradual growth rather than significant. The implementation of inclusive education has not been running smoothly. The data from UNESCO shown that the ranking continue to decline. In 2008, Indonesia was in the 63rd rank and in 2009 was in the 71 st and continue declining. In fact, the school enrollment rate is still low, only $34,2 \%$ (Poernomo, 2016).

The goal of inclusive education in all school is not easy to achieve. One obvious obstacle is due to teacher's negative attitude towards the acceptance of inclusive education. A relevant study measuring teacher's perception towards the implementation of inclusive education in all public high schools in Surabaya revealed that not all teachers could accept inclusive education and teachers are lacking of understanding (Suryani, 2014). Studies conducted by Boucher (1981) and Rizzo (1984) have generally found that the overall attitude of general education teachers tends to be negative towards students with disabilities (Ingram, 1996).

Inclusive education represents a major change for most school organizations. Teachers may feel resentful for having to bear extra responsibility, pressured by additional demands on strained workloads, and incompetent owing to lack of training and preparation for the task (Ingram, 1996). 
In spite of this, Bass (1985) stated that leadership behavior of the principal influences teacher's motivation towards goal expectation, and the successful implementation of innovation and change in school. It is logical, then, to assume that the leadership practice of the principal may influence the way in which inclusive education is accepted, not only by teachers, but whole school stakeholders.

In addition, an analysis of new 'zoning-based school' system implemented by the government in June 2019, created a significant impact on student enrollment in all state high school across the country. Before June 2019, student enrollment were based on purely academic achievement, i.e. a combination of individual national exam result and student's academic potential (TPA) test. All secondary public schools in the city are standardized in terms of quality, and are fully financed by the government. Students are free from school fee. Therefore, parents are keen to send their children to public schools although its competition is very tight every year. For favourite schools, only students whose grades with minimum 80 in national exam, and passed TPA test are accepted in those schools. As a result, students in secondary public schools tend to be homogeneous in terms of its student's intellectual, life style and social background.

However, with the implementation of 'zoning-based school' in July 2019, student's enrollment is not based on academic test anymore but by geographical distance, a distance between home and its public schools in those zoning areas. The closer the distance, the bigger chance to get acceptance. This 'zoning-based school' system has impacted secondary public schools in several areas: (1) More diverse students in school than before. (2) There will be unprepared teachers involved in teaching and learning process for diverse students (3) There will be unprepared school principals to manage more diverse school. For this reason, an insightful mindset and skills for inclusive education services are needed. The schools should be dragged towards inclusive schools by all school stakeholders.

The current educational policy challenged school principals to immediately acquire new skill in managing more diverse students, and develop inclusive education. In the new environment, the conservative school's notion of applying one general approach to all students soon will not be applicable anymore. As stated by Richi (2000) the idea of all students should be accultured into a single way of knowing or behaving is under challenged. Under new environment, schools are for all children. As mentioned by Richi (2000) that serious attention should be taken to promote and acknowledge all students, whatever their personal characteristics or social backgrounds are. All can succeed in school.

In this study, the leadership roles of principal in respond to diversity and establishing inclusive education in school will be explored. Begin with its leadership role in fostering new vision, promoting inclusive practices within school and building connection between school and community.

Research questions

1. How are the leadership practice of the principal in building the inclusive educational system at school? What are the principal's set of actions in building the inclusive educational system at school?

\section{LITERATURE REVIEW}

\section{A. The Role of School Principal in School Reforms}

Principals occupy positions that carry unique responsibilities and opportunities, and they work within a particular tradition of practice with its own strengths. In building level administrator to shaping inclusive school, this study does not intend to isolate that role of others in the social and political fabric of the school, nor to overstate the importance of the formal school's leader, but 
instead to help clarify the contributions of those who hold a well-established position and to suggest ways in which their work can be more effective.

Burns (1978) proposed a new theory of leadership, i.e., transformational leadership which have shown to have a greater impact on change in attitudes of subordinates. Transformational leaders, according to Burns (1978), raise followers' consciousness levels about the importance and value of shared goals and how to achieve them. Transformational leaders motivate followers to transcend their own self-interests for the vision of the organization. Transformational leaders motivate by tapping higher order needs of followers. Bass and Avolio (1990) suggest that transformational leaders inspire followers with a vision of what can be accomplished through extra personal effort, thus motivating followers to achieve more than they thought they would achieve. Bennis and Nanus (1985), found that transformational leaders empower followers thereby helping them to develop competence necessary to achieve organizational goals.

Tichy and Devanna (1986) studied the process by which transformational leaders move large organizational through major change. They found that transformational leaders move through three phases in the process of transforming the organization. First, the transformational leader recognizes the need for change and persuades key people in the organization of the seriousness of the need. Second, the leader involves key people in the development of an inspiring vision of the future. Finally, the leader mobilizes commitment to the new vision.

Sergiovanni (1991) suggesting a need to add moral authority to bureaucratic systems, implies that a set of shared values and beliefs that spell out from leaders, what they want to accomplish and how, will increase teacher motivation and commitment to effective teaching and learning.

Education reform have indeed broadened the role of principals. The roles that are more demanding, such the following (1) build teams, (2) establish vision (3) cultivate teacher's leadership skills (4) use data to inform instruction (5) observing and implementing reform guideline, and (6) in the context of education reform, principal should be able to integrate managerial and instructional responsibilities (Ganon-Shilon, 2018). Principal implementing reforms should not anticipate session to rest, as they need to keep going redefine policies to suite particular situation that necessarily influence a successful reform implementation,

Furthermore, school reforms demand principal to divide between two competing fields both external and internal activities of organization. Internal activities, such as gathering information about school's needs and problems, persuading and motivating member to set prioritize that support school's new goals. Examples of external activities are building relationship with community, and acting as the bridge between the school and external stakeholders. (Ganon- Shilon, 2018). In addition, principals also need to engage in professional activities, both pedagogical and managerial. In this case, principals act within a more complex network as they need to integrate the school with external environment within a reform context. Principal needs to seek partnership with various parties and stakeholders through ongoing dialogue and social interaction (Ganon-Shilon 2018).

Heller and Firestone (1995) challenge the idea of heroic leaders in school reforms (1) providing and selling a vision, (2) providing encouragement and recognition (3) obtaining resources (4) adapting standard operating procedures (5) monitoring the improvement effort (6) handling disturbances. Interestingly these functions are seen as considerably overlap with factors that have been identified as critical for the success of inclusive education (Mayrowetz \& Weinstein, 1999).

\section{B. Principal as the Agent of Change of Inclusive Education}

Many studies have revealed the importance of the principal's role as instructional leader as well as agent of change in schools (Bossert et al., 1982; Sweeney, 1982 in Hallinger, 2015; Blumberg 
and Greenfield, 1986, in Thornburg, 2015). A similar opinion Okeke (2019) revealed that the principal was the most important element in the school. The principal's behavior significantly influences any matters that happen in school (Hallinger, 2015) and to create an effective school (Andersen et al, 2005).

Based from various literatures, the main tasks in promoting inclusive practices within school centralized around two dimensions: promoting forms of teaching and learning that enable diverse students to succeed and strengthening school cultures that support diversity. In this case, Principal can act in direct ways to impact the school culture. Molding and strengthening inclusive school cultures.

Riehl (2000) stated that in fostering new meaning about diversity in school, much of the literature on school reform suggested towards professional development and technical internal processes to schools, especially activities of teaching and learning. New (or renewed) instructional methods, new organizational configurations, new forms of assessment and accountability, and new norms of teacher practice that emphasize collaboration and professional growth are examples of reform initiatives.

However, numerous analyses of educational change have demonstrated that school reform will not take place unless whole organization, including students, parents, the general public, educational teachers and professionals understand and invest in the changes (Metz, 1990b; Tyack \& Cuban, 1995). Similarly, Van Dyke (1995) stated that inclusion program is not successful if the principal does not take active actions and positive roles in the process. In this regard, the role of the principal is crucial. According to Van Dyke, the principal's role is (1) to set up inclusion committee (2) to support teachers and assist staff member in transition towards inclusion (4) to address parents, community and school's stakeholder concern about inclusion (5) to manage school logistics of inclusion.

Another study stated principal's role is to build and maintaining trusting relationship (Shelden et al, 2010). This includes (1) developing vision of trustworthy school, (2) serving a role model for trustworthiness through language and action, (3) build teacher's competencies, (4) improving discipline among students and teacher, and (5) conflict mediator. In addition, principal must also negotiate socially through a shared process.

School principals typically have additional power in defining situations and their meanings of new concept of school (Miron, 1997 as cited in Riehl, 2000). As the formal leader of school, principal can possibly have an affirmative role in create schools that are more inclusive and that serve diverse students more effectively (Tyack, 1974). As in most social movements, it is expected that the formal head of organization will act as the agent of change.

One of the assumptions embedded in the scholarly literature on school administration and diversity written from a critical theory perspective is that a genuine commitment to diversity would require principals to attend to the fundamental inequities in schooling, to work toward larger projects of social and institutional transformation. This perspective portrays the practicing principals as conservative. The reason is that according to Foster, (1986) and Parker \& Shapiro (1993) schooling is inherently a conservative context in which racism, classism, and sexism are present but subsumed under a fiction of tolerance between social groups and a myth of neutrality about administrative work. Some scholars suggest that administrators who do become committed to social change will experience conflict as they are expected to move towards new direction whilst maintain existing institutions which they no longer see as legitimate (Rizvi, 1993).

\section{Principal's Leadership Behavior for Inclusive School}

Leadership can be dispersed across many people and roles in educational contexts, and is usually more effective as a distributed practice (Barth 1990) - focus here on the school principal. Inclusion of moderate and severely disabled students, a slow, but growing phenomenon, represents 
a major change for most school communities. Studies have shown that the successful implementation of innovation and change in schools is related to leadership behavior of the principal (Bowers, 1990). It is logical, then, to assume that the leadership behavior of the principal may influence the way in which inclusion is accepted and implemented by teachers. Gano-Shilon (2018) argued that Successful reform implementation depend largely on the extent to which principal accept, reject or adapt external reform demands. This implies that principal's words, choice and actions have large impact on the institutionalization of education reforms.

One example is in the case the effort to rejoin disabled students with non-disabled students in the same classrooms. This has raised several important and sensitive issues. Aside from the issues of acceptance by peers and their parents, adaptability of the curriculum and instructional methodologies, and teacher attitudes, both positive and negative, the role of the principal in inclusion efforts warrants particular consideration. The leadership behavior of the principal is viewed as a pivotal role in promoting effective acceptance and implementation of school wide change (Hall and Hord, 1987).

Effective inclusion of students with moderate and severe disabilities in regular classrooms is likely to be a very challenging undertaking (Stainback and Stainback, 1992) and therefore may require, among other things, extraordinary efforts on the part of regular education teachers. In support of this likely need of extra teacher effort, principals as a leaders play an influential role in motivating teachers to succeed in the inclusion of disabled students in regular classrooms. The leadership behavior of the principal influences teacher motivation towards goal expectation (Bass, 1985).

The efficacy of achieving changes and meeting new challenges which provide equal educational opportunity for all students is dependent, in large part, on the principal's leadership and ability to influence teacher motivation. The transformational principal is more concerned with the development of shared values and beliefs, meanings, and commitment to common goals. The inclusion of moderately and severely disabled students represents a major change for the vast majority of staff in regular education settings. The successful implementation of inclusion programs may require a change in the very culture of the school.

In inclusive schools, it is critical that the principal identify and articulate a philosophy, a vision, that reflects the belief that all children can learn, that all children have the right to be educated with their peers in age-appropriate regular education classrooms, and that meeting the educational needs of all children is the responsibility of the school system and staffs.

\section{RESEARCH METHOD}

\section{A. Research Design}

The researcher used the explanatory approach method in conducting qualitative research. This is in line with the explanation from Yin (2011) that case study research is appropriate to be used in explanatory research, since the research intended to explore the explanation of causality and the processes contained in the object of the study. The qualitative approach itself in Zikmund (2003) is used to explain and confirm the nature problem. The size of the depth of the study is not negative but an explanation with words. The researcher uses himself as a research tool.

This research was conducted using a case study method. Case studies are research strategies that answer the question "how (how)" or "why (why)" are proposed, researchers do not get full control of events, and the focus of research on contemporary phenomena that occur (Yin, 2003). Some literature refers to Yin (2011) as a reference in carrying out case study methods and doing so for the same reason Yin (2003), Eisenhardt and Graebner (2007) even expressed the opinion that the findings in case studies can develop theories. 
Single-case studies are used as research experiments used to discuss current topics. Still in Yin (2003), the purpose of case studies is basically for analytical generalizations (first-level inference) that is case study findings will have implications for policy and theory development.

\section{B. Types and Data Sources}

\section{1) Primary Data}

Sekaran (2006) explains primary data is data obtained directly from the first source, such as data obtained from individuals directly on the field through interviews and observations. It involves the latest and previous recordings, or public or private recordings, which can consist of writing, publications, sound recordings, photographs, or video recordings (Chooper and Schindler, 2011).

\section{2) Secondary Data}

Chooper and Schindler (2011) explain that secondary data is material made by parties other than researchers and has specific objectives. Materials in the form of company data archives can be explored by researchers as research objects. Documents or publications are the second source of secondary data made by outside parties other than the object of research. The form is in the form of news or web pages. Still from the explanation of Chooper and Schindler (2011), secondary data can help researchers determine what needs to be done and become a source that is rich in hypotheses but requires high creativity in the search process.

\section{Procedure for Data Collection}

\section{1) Archival Records}

In this study the data collection method used consisted of a study of literature, namely collecting materials in accordance with the topic of this research, this step is also known as an archival record. The material collected from the literature and statistics then converges as an object to be observed by researchers using an in-depth interview approach. The results of the interviews were recorded, then written as words in the interview transcript. It is through this transcript that the results can be used as material for research discussion.

\section{2) Individual Depth Interview}

A more detailed discussion of in-depth interviews is explained by Chooper and Schindler (2011), Individual depth interviews are interactions between an interviewer and a single participant on an interesting issue or topic and uses a connected method. Indepth interview procedures are carried out by direct meeting with the speaker for 40 minutes to 60 minutes. After first sending permission to study and attach interview guidelines, they were also followed up by phone.

\section{3) Sampling}

The researcher used purposive sampling, then chose judgment sampling because the sample was chosen by the researcher based on the assessment that the informant was the most appropriate party from very few people to be used as research samples and could provide the information sought (Sekaran and Bougie, 2009). In line with that, Zikmund (2003) explains that it uses purposive sampling, that has unique characteristics related to experience, attitudes, or perceptions as concepts or theoretical categories as a result of participants during the interview process.

The main data collection is from DR. Triworo Parnoningrum M. Pd. as the headmaster of SMPN 28 Surabaya, she was chosen for her achievement as the Best Principal in Surabaya on February 2019. She is the pioneer of Inclusive School in 
Surabaya. We also interviewed Head of Education in the city, child-friendly school team, vice principal, special education teachers, and general teachers.

\section{4) Triangulation}

Flick et al (2004) explain that triangulation is important and unique in using procedures that are combined to equalize values. Triangulation in this study applies the method of Shah and Corley (2006), which is used to test validity by triangulating the data type and type of methodology. The next step carried out by the researcher is the analysis carried out on the results of data collection using data using explanatory building.

\section{Data Analysis Techniques}

Yin (2003) explained that the selected case could be evidence of the theory being developed. Case study in this type, the number of analysis units used in general is only one.

\section{FINDINGS AND DISCUSSION}

\section{A. School Profile}

28 State Junior High School Surabaya is in western of Surabaya. It has 1187 students consisting of 517 male students and 617 female students. The school has 54 teachers and 19 nonteachers. With 33 classrooms, 3 laboratories, 4 sanitation rooms. The learning process takes place full day, five days / week. In each class, on average there are 36 students including 2 students with special needs. Students with special needs received there with these types:

- Deaf are individuals who have permanent or non-permanent hearing loss.

- Developmental impairment is an individual who has a significantly below average intelligence and is accompanied by an inability to adapt behaviors that arise during development. (https://id.wikipedia.org/wiki/Anak_berkebutuhan_khusus)

- Tunadaksa is an individual who has a movement disorder caused by neuro-muscular abnormalities and bone structures that are congenital, sick or due to accidents, including cerebral palsy, amputation, polio, and paralysis. The level of disability in the physical disability is mild, that is, it has limitations in carrying out physical activity but can still be increased through therapy, that is, having motor limitations and experiencing sensory coordination disorders, severe, namely having total limitations in physical movement and being unable to control physical movements.

- Autism is a nervous system development disorder in a person which is mostly caused by heredity and can sometimes be detected since the baby is 6 months. Autism sufferers can also experience problems in learning, communication, and language. [1] Someone said to suffer from autism when experiencing one or more of the following characteristics: difficulty in interacting socially qualitatively, difficulty in communicating qualitatively, showing repetitive behavior, and experiencing developmental late or abnormal.

- Double disability

At present, the total number of students with special needs is 63 PDBK (Student's classification with special needs), with a comparison of grade 9 there are 10 PDBK; in class 8 there are 16 PDBK, and in class 7 there are 37 PDBK. The headmaster has been carrying out his duties as a principal at 28 State Junior High School for 3 years.

- School Principal's role in developing inclusive education for diverse students.

\section{B. Changing Mindset of The Teachers and School Members}

The principal conducts a coordination meeting to change the mindset. This coordination meeting was attended by all teachers, non-teacher parents' representatives from each class, school committees, all OSIS administrators and related institutions around the school including doctors at the puskesmas, representatives from the kelurahan, kecamatan, Polsek and Babinsa (Bintara Pembina Desa - under the command of the Koramil (Military District Command)). 
According to McLeskey \& Waldron (2019) at the beginning of the change process, principals need to hold a thorough open discussion with teachers, with the aim of ensuring support before starting the process of change, to determine certain rooms (e.g., more accommodating general education classrooms, behavior better expected behavior, improved reading achievement. This needs to be the focus of initial change, and to begin the development of a shared vision of successful education for all students. This discussion ensures that all teachers understand, understand and appreciate the fact that all students are important (including students with disabilities), and the changes that will be made are to accommodate and provide better support for all students in the school.

The principal said "This Coordination Meeting is very important to be carried out so that all school members can jointly develop the school in the same mission and vision. In addition, a coordination meeting was held to review again that school is a form of education service for all children (education for all) without distinguishing the race, ethnicity, class, status and physicality of a person. Every child has the right to get educational services without violence. Children have the right to feel comfortable and safe while in school. And that can all be realized if done in one vision."

Reform initiatives, and reform behavior must be started from the principal by involving all school stakeholders as stated by McLeskey and Waldron (2019) that changes in school organizations are two-way support, namely from above and below. According to Metz, 1990; Tyack \& Cuban. 1995) school reform will not succeed unless it involves stakeholders widely, including students, parents, the general public, and educators themselves, where all lines must understand the changes that occur and want to invest in change (Riehl, 2009). To achieve the necessary changes, general and special education teachers must support and be involved in the planning and implementation of inclusive schools. Inclusion is not merely a matter of "special education" but requires a change in the professional practice of all teachers in schools (McLeskey \& Waldron, 2019).

The first obstacle encountered in changing this mindset is that team members are not yet fully open to inclusive schools and assessing inclusive schools will only add to the workload. This is in line with previous research conducted by Suryani \& Sudarto (2014) about the perception of SMPN teachers in Surabaya regarding the implementation of inclusive schools in Surabaya found that only $25 \%$ of respondents were able to receive inclusive education in state junior high schools, and one of the obstacles was the lack of understanding of children with special needs and inclusive education itself. Research conducted by Mngo \& Mngo (2017) also says that although teachers support inclusive education, they still want separate classes between regular students and inclusive students.

Meanwhile, experts and inclusive educators say that students who are not alienated in the learning process can do things better than students who are alienated from their environment (Van Dyke, 1995). Separating children from the school environment throughout the day is not good because it will further widen the difference.

Some things that are done by school principals to overcome resistance include (1) Establishing interpersonal communication, both with internal and external parties of the school by continuing to coordinate internal and external schools. (2) Expanding networks supporting inclusive education in schools (3) Resolving any differences of opinion in consensus deliberation while continuing to promote the right of children to get the best education services (4) to adopt a religious approach.

This is in line with a study conducted by Anderson (1990 in Reihl, 2009) which explains three strategies used by principals in interpreting diversity in schools (1) sharing a vision: through daily management of all organizational stakeholders, (2) conducting mediating conflicts when open conflicts arise, and (3) through providing cognitive tasks to resolve differences in perspective between members.

"There are no significant obstacles because we together overcome the difficulties that exist by always sharing together to get the best solution. Changing one's mindset is not as easy as turning one's hand. We need time and process to achieve it. But we always try as much as possible to spread positive values so that around us also accept it well and negative things can be eroded by itself. What is still doubtful is very reasonable, due to lack of information. The most important thing is to understand that children's rights must take precedence regardless of the conditions. " 
In changing mindset, there is a slight difference between teacher and non-teacher. Teachers who have a pedagogical education background are considered to better understand the characteristics of children, and it is easier to be given insights into inclusive education, by linking them to the subjects they teach. While the non-teacher does not have a pedagogical education background, the approach is more personal first, then together understanding the needs and rights of students at school. Until finally the non-teacher staff can also understand the characteristics of different children.

In changing mindset and building vision, the role of the principal is very important. As agent of change in the school of Bossert et al., 1982; Sweeney, 1982 in Hallinger, 2015; Blumberg and Greenfield, 1986, in Thornburg, 2015) School principals need to carry out intense communication and social negotiations about the meaning and significance of their vision. As administrator, the principal is in the best position to instill the vision of inclusive schools.

Another approach taken by school principals in changing mindsets is through the Religious Approach. To change the mindset, at every opportunity, the principal always incorporates a religious approach to open the hearts and minds of the teachers and staffs. The principal believes this is a very useful approach.

"Every individual has a belief in the greatness of God who has given his gift to humans as khalifah (leader) on this earth. Every individual on earth has a nature of each with a unique diversity. As a caliph, he should lead and give the best for every human being."

This principle is in line with Muslim values. Muslims in their prayers always pray to Allah to reach happiness of living in the world and the happiness of life in the hereafter (see QS Al Baqarah: 2001). As Allah said in the Quran "...And I did not create Jin and Men except to worship me" (QS adz-Dzaariyaat: 56), hence Individual as a Khalifa (God servant) in this world should live and do their activities merely and unconditionally to worship Allah. This indicates a perspective that people in carrying out activities including activity in the organization will maintain balance and harmony between the world and the hereafter.

The principal said, "Guided by this, the teachers and staffs are expected to be able to provide knowledge and spread affection to students at school so that they become virtuous children."

The idea of a spiritual approach comes from the personal experience of the principal and religious beliefs and the values he believes that the knowledge he has must be able to bring benefits to society and children.

"I got the idea because of the calling of the soul to serve the children who are excluded so that they will be able to be effective in the middle of society. No matter how small a person's ability we can be appreciated because all humans are creatures created by Allah SWT "

Below are examples of sentences the principal usually use to communicate with the team:

"God never fails in his creation, every individual is special with all the potential, talents, abilities and uniqueness"

"To change the environment, apply $3 \mathrm{M}$ (starting from yourself, starting now, starting from small ones)."

"Give the best at every point we are, inshaa Allah that's where our practice seeds are planted"

"Serve the people as well as possible, inshaa Allah the needs of our lives will be served by Allah SWT."

"Do five cases before five other cases come."

"Confident that every goodness has been prepared 100 times the goodness of Allah SWT."

According to Zaman et al. (2015 in Tasrim et al, 2020) Islam provides a clear reference of every aspect of life and provides a brief discussion and practical examples on the expected Muslim behaviors, such as sincere relationships among people, helping the poor, helping the weak and the sick, helping others in needs are important values. Muslim are also to expected to show certain behaviors, for instance five times praying a day, fasting during Ramadan, pilgrimage (pilgrimage) and zakat, sedekah and help individuals avoid wrongdoing and speech. Under Islamic perspectives, recognize and practice community norms such as justice, harmony, good relations with fellow human beings because all humans are brothers and sisters (diversity), equality is defined as a cooperativeness and obedient to serve God and also to create meaningful life. 
From various approaches taken, the principal can recognize and know that one's mindset has turned positive through several things: (1) Someone will appear when giving learning with a loving heart. (2) Seeing that all children need educational services that the same without discrimination (3) Serving their students as serving their own children. (4) Carry out teaching with joy and enthusiasm as a sign of his heart being happy.

\section{Strengthening Inclusive Culture}

Previous research revealed that school reform, from public schools to inclusive schools can be directed at 2 (two) things, namely the professional development process and internal technical processes in schools, especially those related to teaching and learning activities (Van Dyke, 1995; Majoko, 2019; Reihl, 2019)

Through meetings and brainstorming, inclusive mindset, knowledge and skills are strengthened. For training \& services in school, the principal invited some experts to the school. There are many experts who are brought to school to do learning to school members. In this case the headmaster facilitates the teacher and staff to adapt to the new school concept desired, by inviting mentors and motivators to provide training. Those invited included among others are from:

- Women's empowerment and child protection agency related to children's rights at school

- From local health centers doctors and psychologists related to health.

- From the Police Department / military regarding the applicable law on school safety

- From the law and the prosecutor's office about the bullying Act.

- From the Office of Education on children's rights to education.

- From outside Psychology or NGOs engaged in the field of Education for Children (Genta)

- From DP5A Surabaya and Puspaga.

- From the P4GN (anti-drug) team

- From Fasna, child-friendly school.

- $\quad$ From related LPTK (PLB-Unesa, Psychologist-Airlangga University Surabaya)

In one year, the principal can invite more than three experts to conduct training. What the principal does to find and get expert mentors is to actively build networks that can support the development of inclusive education and always open themselves to new things.

Of the many trainings that have been carried out at the school, the principal considers that the training conducted by the team of psychologists is the most important and has the most significant impact on school residents. The team of psychologists as motivators and opening insights into each team member, by saying that each child has strengths and weaknesses. One must make weaknesses and weaknesses in students as a strength to continue to achieve their goals, and not make strengths as pride.

Reform of teacher education is fundamental to this process (Forlin, 2010; Pantic \& Wubbels, 2010). Teacher educators not only need to examine the attitudes of their students toward diversity and its accommodation but also to undertake "self-study and internal evaluations to better understand their student capacity to infuse diversity issues throughout the curriculum" (Brisk et al., 2002, p. 7, as cited in Kuyini et al., 2016).

This training and professional development for teachers is very important considering that from previous research conducted in the same population it was found that the main obstacle in the implementation of inclusive education in SMPN Surabaya was the lack of teacher's ability to provide special services to children with special needs and lack of teacher knowledge. in understanding the characteristics and needs of children with special needs (Suryani \& Sudarto, 2014).

According to Mngo \& Mngo (2017) teachers who have undergone training and have experience will be more supportive of inclusive education. Teachers who lack experience and do not receive training tend to be less enthusiastic about seeing the benefits of inclusive schools, including teaching in mixed classes where there are students with special needs. This indicates that resistance comes from the lack of training and preparation of the teacher himself. Furthermore Majoko (2019) said that teachers for inclusive schools do indeed require unique competencies, which are not shared by teachers in general. In the Majoko study (2019), the CEC (Council for Exceptional Children), a high institution that handles the education of children with special needs, has announced several key competencies needed for effective teaching of inclusive education in 
regular classrooms. Inclusive schoolteacher competencies include knowledge and skills regarding teaching strategies and approaches that suit the needs of all children.

In regular classes (Ainscow \& Goldrick, 2010; Florian, 2009; Forlin \& Sin, 2010; Hornby, 2010 as cited in Mjoko 2019). These skills enable teachers to plan flexible teaching and to recognize the reality of individual differences and differences between students, but teachers are still able to adjust learning goals, content, and create an environment according to individual and whole class needs (Agbenyega \& Deku, 2011; Ainscow \& Goldrick, 2010; Florian, Young, \& Rouse, 2010 as cited in Majoko 2019).

In terms of funding training and skills for teachers and staff, the school has a school budget plan for making activities related to financing. This depends on the needs of each year. Other funding sources come from BOPDA (Regional Education Operational Assistance) \& BOSNAS (National School Operational Assistance).

In addition to bringing in mentors, another method used by principals to promote and strengthen the culture of inclusive schools is

- The principal explores the creativity of teachers who have the expertise to innovate to improve inclusive education in schools.

- In addition, principals often create activity programs that involve regular students and students with the need to mingle and work together. The involvement of regular students and PDBK (classifying students with special needs) has begun at the time of the admission of new students at school. In one week of the school introduction orientation program, regular students and PDBK undergo activities together.

- Principals hold contests related to exploring the interests and talents of PDBK (student's classification with special needs) with guidance involving the student department and OSIS participation as a driving force.

- The school principal elects and engages "Inclusive Ambassadors" from regular students as a companion to PDBK or peer tutors with the aim to foster empathy in their hearts.

- The principal conducts social activities that always involve students with disabilities to foster the confidence of students with disabilities and eliminate discrimination.

- The principal and the team of teachers create an extracurricular learning program by involving all students, for example gardening, cooking together, cleaning classes and schools, doing religious activities etc.

- The principal invited and included all the student council members, the teachers as their facilitators and the parent's representative as the observers to conduct several meetings and make 'pocketbooks. This pocketbook contains what may and may not be done by fellow students at school.

According to Van Dyke (2019) involving regular students as a peer companion for students with special needs is a very effective strategy. But the teacher needs to create a strategy model that allows students to be involved in problem solving. Peer support and support can help regular students to build and foster good relations with their friends with special needs. On the other hand, students with special needs who are not isolated in the school environment show better progress compared to students with special needs who are isolated and separated in a different space from their regular friends. This allows students with special needs to develop socially, even some of them really make friends. Classrooms in which there is diversity are believed to be able to enrich the learning of all students involved.

All students learn that everyone has needs and brings strength in every situation. They learn about conflict resolution, and the importance of being responsible (Van Dyle, 2019).

\section{Promoting Inclusive Education Practices in Teaching and Learning}

Individual Assessment. The implementation of the practice of inclusion begins at the stage of admitting new students in grade 7 . The school assesses each student identified with special needs. The assessment process involved several parties: regular teachers, special needs teachers, elementary school special supervisor teachers where ABK (children with special need) attend school, parents, and children with special needs. The assessment covers interviews about the history of the child's condition, family environment and previous school environment, including weaknesses, strengths and needs of children, as well as information from special supervisors in primary schools. There are several types of assessment used: (1) academic assessment in the 
language field (2) academic assessment in the arithmetic field, (3) assessment of gross motor skills (through throwing and jumping), and balance, (4) occupational and speech assessment, behavior and psychological child. The assessment process will produce a PDBK (Student's classifications with special needs) identification report.

Based on the results of the assessment, the teacher team conducted a PPI (Individual Learning Program) according to the results of the assessment agreed by the parents and the school as a reference for the service \& target of the educational outcomes of the remaining special needs in the school within the next year. The information contained in the PPI includes student data, diagnosis results, assessment results, a list of student strengths and needs, a compensatory service program consisting of 3 parts: (1) for communication skills, (2) skills (counting, writing, reading) and (3) self-development program (self-regulation). Each program contains details about the learning plan and the target of achieving individual of children with special needs. This PPI preparation process involves special education teachers, psychologists, medical rehab doctors and subject teachers. (The school develops individual learning programs in accordance with the results of the assessment, the learning contract should be agreed by the parents and the school and is used as a reference of student learning targets. It is used as inclusive education outcomes at the school.

After conducting an assessment and preparation of PPI, the school will make a list of all 7 (seven) grade GDPKs along with their respective photos and determine the placement of the class. This list will be distributed to all teachers teaching in grade 7 . Thus, each teacher in grade 7 will know information about GDPK in each class.

If needed, the teacher team will make modifications to the lesson plans (lesson plans) that have been made. RPP is made on every subject taught in school. With the existence of this inclusive school practice, then in one lesson RPP may have two different learning targets between regular students and ABK (students in need) students. Modifications to this lesson plan are based on individual learning programs that have been stated in the PPI of each PDBK.

According to Van Dyke (2019) it is very important to provide opportunities for each student to actively participate according to their respective levels and to achieve their individual goals. The curriculum might look overlapping. But displaying different material for the same topic with different reading styles has proven to be very effective. The same curriculum is applied to all students, but differences are considered. So, for students with special needs, the implementation of the assessment will be adjusted to the modified curriculum. The application of class promotion is adjusted to the chronological age for students whose academic abilities are below the average standard. Thus, the passing of the graduation exam according to the modification curriculum.

In addition, schools also implement learning practices with UDL (Universal differentiated learning) systems according to curriculum modifications. There are three inclusive school learning models, which are applied namely consultant model, teaming model. Co-teaching models.

Consultant model is an educational service that provides opportunities for children with special needs to learn together with normal children under one roof. To help the difficulties which are experienced by students with special needs, Special Tutor Teachers are provided as consultants for class teachers, principals or PDBK themselves.

Co-teaching model is a joint learning model to develop learning which is a collaboration of two teachers in a mentoring class where one teacher teaches regular students, while the other teacher accompanies students with special needs in regular classes.

The third learning practice is a Teaming model where in providing educational services not only relies on subject teachers but the responsibility of a team that collaborates to build children's characters becomes more positive. This model team works together with all teachers, non-teachers and all school stakeholders.

According to Leskey \& Waldron (2002) both subject teachers and special tutors must both support and be involved in planning and implementing inclusive schools, because schools require changes in teaching practices in a professional manner from all teachers.

The same opinion was announced by Van Dyke (2019) who revealed that in inclusive classes, subject teachers and special education teachers must be able to work together, collaborate with each other to be able to meet the needs of students in the class. Successful collaboration is determined by several things, including (1) honest and open communication, (2) flexibility. Teachers who teach in inclusive classes must always be prepared to anticipate, compromise to do 
something different, if needed. (3) sharing responsibilities. Because PDBK is part of the general class, the ABK teacher in charge will play a role to help PDBK and subject teachers during class.

\section{E. Building Connections Between Schools and Communities}

Effective school principals understand the importance of schools to foster relationships with other organizations and the surrounding community. It aims to position schools to be able to utilize the positive resources offered by other organizations, to protect students (and schools) from negative impacts in the environment, and to provide a variety of services that meet the needs of students and strengthen the communities where they live (Englert, 1993 as cited in Reihl, 2009).

Community service with parents, students, teachers \& employees. Picket Parents of students at school to check the needs of their sons and daughters in class. In addition, the principal made an exhibition program the work of parents and school collaboration students. The principal plays an important role in creating and increasing stakeholders 'trust, parents' trust in the school, trust between parents and teachers, including trust that results from interactions between the principal and students

can influence children's overall perception of school (Shelden, 2010).

Because this school is a public school, the school has a fairly intense relationship and involvement with government institutions, especially the Surabaya city education office. Some programs from this inclusive school have the support of the city government both in terms of funding and assistance of special advisors.

Government initiatives to support secondary public schools in developing inclusive education in Surabaya

- The government facilitates schools to sign MOU on Child Friendly Schools \& related institutions. Facilitating schools to establish MOU Child Friendly Schools and related institutions

- The government conducts training for principals, vice principals and BP teachers to train personal sensitivity to the needs of different children.

- The government formed a discussion \& coordination forum in the form of KKG for SD \& MGPK for SMP. The establish a discussion and coordination forum. Inclusive Education Teachers 'Forum.

- The government appreciates Child Friendly Schools, the formation of peer counselors in schools. Child-friendly school appreciation program, student peer counselor program

- The government held celebrations, races and a stage of appreciation for the talent of interest for the entire GDPK on International Disability Day

- The government provides and prepares a GPK (special tutor) with a psychologist background with payroll provided by the government. Provide teacher's counselor (community psychologist) to support schools

- The government aids in the provision of infrastructure facilities that are accessible to GDPK for schools that provide inclusive education. infrastructure facilities that are accessible to special needs students for all schools that carry out inclusive education

- The government provides incentives, encouragement for inclusive schools to conduct budgeting that is more directed at child-friendly service programs in schools. providing incentives for schools implementing inclusive education to develop budgets that are more directed to support child-friendly service programs at schools

\section{CONCLUSION}

With the implementation of the school zoning system in Indonesia, schools are required to accept students with diverse backgrounds including accommodating students with special needs and becoming more child-friendly schools. This challenge was positively responded by the principal who appeared from the leadership behavior and a series of strategies carried out which included changing the mindset of all teams and school stakeholders by means of routine coordination meetings, overcoming resistance directly, and incorporating approaches with religious values. Along with the process of changing this mindset, the principal invited inclusion education experts and mentors to train teachers and staff as a form of professional development and to upgrade 
knowledge and experience knowledge about inclusion. The principal also involves regular students, student council officials by forming an inclusive ambassador, and always includes regular students and students with special needs in the activities simultaneously both inside and outside the classroom. In collaboration with the local education office, the school principal utilizes special education teachers who are the support of the government, to collaborate with BK teachers and subject teachers in assessing students with special needs upon admission of new students; make PPI (individual learning program) for each child with special needs; modifying lesson plans (lesson plans); and according to the need to do a consultant model learning, teaming model Co-teaching model. The principal also always involves and establish communication with parents in various activities, as well as collaborating with various parties and successfully obtaining full support from the local government.

\section{REFERENCES}

Anderson, R. E., \& Dexter, S. (2005). School Technology Leadership: An Empirical Investigation of Prevalence and Effect. Educational Administration Quarterly, 41(1), 4982.doi:10.1177/0013161x04269517

Barth, R. S. (1990). Improving schools from within: Teachers, parents, and principals can make a difference. San Francisco: Jossey-Bass, Inc.

Bass, B. M. (1985), Leadership and Performance beyond Expectations, the Free Press, New York, NY.

Bass, B. M. and Avolio, B. J, (1990), Transformational Leadership Development, Manual for the Multifactor Leadership Questionnaire, Consulting Psychologist Press, Palo Alto, CA.

Bennis, W. and Nanus, B. (1985), Leaders: The Strategies for Taking Charge, Harper \& Row, New York, NY.

Bowers, B. (1990), Initiating Change in Schools, National Association of Elementary School Principals, ERIC Document Reproduction Service No. ED 315909.

Burns, J. M. (1978), Leadership, Harper \& Row, New York. NY.

Chooper, Donald R. And Schindler, Pamela S. 2011. Business Research Methods. New York : McGraw-Hill.

Eisenhardt, Kathleen M. Dan Graebner, Melissa E. 2007. Theory Building From Cases : Opportunities and Challenges. Academy of Management Journal, 1 (50): 25-32.

Flick, Uwe, Von Kardorff, Ernst, Steinke, Ines. 2004. A Companion to Qualitative Research. London : SAGE Publication.

Ganon-Shilon, S., \& Schechter, C. (2018). School principals' sense-making of their leadership role during reform implementation. International Journal of Leadership in Education, 122. doi:10.1080/13603124.2018.1450996

https://id.wikipedia.org/wiki/Anak_berkebutuhan_khusus

Hall, G. E. and Hord, S. M. (1987), Change in Schools: Facilitating the Process, State University of New York Press, Albany, NY.

Hallinger, P. (2015). The Evolution of Instructional Leadership. Assessing Instructional Leadership with the Principal Instructional Management Rating Scale, 1-23. doi:10.1007/978-3-31915533-3_1

Ingram, P. D. (1996). Leadership behaviors of principals in inclusive educational settings, Vol. 35 Iss 5 pp. $411-427$.

Ingram, Patreese D. 1997. Leadership Behaviours of Principals in Inclusive Educational Settings. Journal of Educational Administration, Vol. 35 No. 5, pp 411-427.

Leithwood, K. A. (1992), "The move toward transformational leadership", Educational Leadership, Vol. 49 No. 5, pp. 8-12. 
Majoko, Tawanda. (2019) They Key Competenciew for Inclusive Education : Tapping Pragmatic Realities of Zimbabwean Special Need Edication Teachers. https://doi.org/10.1177/2158244018823455

Mayrowetz, David and Weinstein, Carol S. 1999. Sources of Leadership for Inclusive Education : Creating Schools for All Children. Educational Administration Quarterly Vol. 35, No. 3 (August 1999) 423 - 449.

McLeskey, J., Waldron, N. ( 2002) School Change and Inclusive Schools: Leasson Learned from Practice. The Phi Delta Kappan vol.84.No. 1. Pp. 65-72

Metz, M. H. (1990b). Real school: A universal drama amid disparate experience, in D. E. Mitchell and M. E. Goertz (Eds.), Education Politics for the New Century (pp.5-91). London: Falmer Press.

Mngo, Z. Y., \& Mngo, A. Y. (2018). Teachers' Perceptions of Inclusion in a Pilot Inclusive Education Program: Implications for Instructional Leadership. Education Research International, 2018, 1-13. doi:10.1155/2018/3524879

Okeke, Ndidi. (2019) School Technology Leadership: New Concept. International Journal of Innovative Development and Policy Studies, 7(2):50-56,

Pivik, Jayne, McComar, Joan and Laflamme Marc. 2002. Barriers and Facilitators to Inclusive Educatio. Council for Exceptional Children Vol. 69, No. 1 pp. 97 - 107.

Poernomo, Baby. (2016) The Implementation of Inclusive Education in Indonesia: Current Problems and Challenges. American International Journal of Social Science, Vol.5,No.3

Riehl, C. J. (2009). The Principal's Role in Creating Inclusive Schools for Diverse Students: A Review of Normative, Empirical, and Critical Literature on the Practice of Educational Administration. Journal of Education vol 189: (pp. 183-197).

Riehl, Carolyn J. 2000. The Principal's Role in Creating Inclusive Schools for Diverse Students: A Review of Normative, Empirical, and Critical Literature on The Practice of Educational Administration. Review of Educational Research Spring Vol. 70, No. 1, pp. 55 -81.

Rizvi, F. (1993). Race, gender and the cultural assumptions of schooling. In C. Marshall (Ed), the new politics of race and gender. The 1992 Yearbook $\mathrm{f}$ the Politics of Education Association (pp. 203-217). Washington, DC: Falmer Press.

Sekaran, U. (2006). Metode Penelitian Untuk Bisnis 1. (4th ed).Jakarta: Salemba. Empat.

Sekaran, Uma dan Bougie, Roger. 2009. Research Methods for Business : A Skill Building Approach. West Sussex : John Wiley \& Sons.

Sergiovanni, T. J. (1991), The Principalship: A Reflective Practice Perspective, $2^{\text {nd }}$ ed., Allyn \& Bacon, Boston, MA.

Shah, S.K. and Corley, K.G. 2006. Building Better Theory by Bridging the Quantitative-Qualitative Divide. Journal of Management Studies, 43:1821-1835.

Sheehy, Kieron and Budiyanto. 2014. Teacher's Attitudes to Signing for Children with Severe Learning Disabilities in Indonesia. International Journal of Inclusive Education Vol. 18, No. $11,1143-1161$.

Shelden, D. L., Angell, M. E., Stoner, J. B., \& Roseland, B. D. (2010). School Principals' Influence on Trust: Perspectives of Mothers of Children with Disabilities. The Journal of Educational Research, 103(3), 159-170.

Stainback, W. and Stainback, S. (1992), "Schools as inclusive communities", in Stainback, W. and Stainback, S. (Eds), Controversial Issues Confronting Special Education: Divergent Perspectives, Allyn \& Bacon, Boston, MA, pp. 29-43.

Sunardi, Mucawir Yusuf, Gunardi, Priyono, and John L. Yeager. 2011. The Implementation of Inclusive Education for Students with Special Needs in Indonesia. Excellence in Higher Education 2 (2011): 1 - 10. 
Suryani, Ima Ayu dan Sudarto, Zaini. 2014. Persepsi Guru Reguler Terhadap Penyelenggaraan Pendidikan Inklusif di SMPN Se-Kota Madya Surabaya. Jurnal Pendidikan Khusus UNESA.

Thornburg, D., Mungai, A. (2016) High-Need Schools: Changing the Dialogue. Sense Publishers Netherland

Tichy, N.M. and DeVanna, M. A. (1986), the Transformational Leader, Wiley \& Sons, New York, NY.

Tyack, D. B., \& Cuban, L. (1995). Tinkering toward utopia: A century of public school reform. Cambridge, MA: Harvard.

Tyack, D.B. (1974). The one best system: A history of American urban education. Cambridge: Harvard University Press.

Yin, Robert K. 2011. Qualitative Research from Start to Finish. London : The Guilford Press.

Zikmund, William G. 2003. Business Research Methods. Ohio : Thomson Learning.

Van Dyke, R.,Stalling, M A.,Colley. Kenna (1995) How To Build and Inclusive Community: A Success Story.The Phi Delta Kappan vol. 76, No. 6, pp 475-479 